\title{
First record of dorsal and anal fin deformities in blue tang Acanthurus coeruleus (Acanthuridae, Actinopterygii) from northeastern Brazil
}

\author{
CAMILA CRISTINA P. DE BRITO ${ }^{1}$, JÚLIO L. ARAÚJO ${ }^{1,2}$, VIVIANA MÁRQUEZ- \\ VELÁSQUEZ ${ }^{1,2}$, MARIANNA B. DA SILVA ${ }^{1}$ AND RICARDO S. ROSA ${ }^{1,2}$ \\ ${ }^{1}$ Laboratório de Ictiologia, Departamento de Sistemática e Ecologia, Centro de Ciências Exatas e da Natureza, \\ Universidade Federal da Paraíba, Campus I - Cidade Universitária, s/n, 58051-900 João Pessoa, PB, Brazil \\ ${ }^{2}$ Departamento de Sistemática e Ecologia, Centro de Ciências Exatas e da Natureza, Universidade \\ Federal da Paraíba, Campus I - Cidade Universitária, s/n, 58051-900 João Pessoa, PB, Brazil \\ Manuscript received on May 31, 2019; accepted for publication on September 22, 2019
}

\begin{abstract}
How to cite: BRITO CCP, ARAÚJO JL, MÁRQUEZ-VELÁSQUEZ V, SILVA MB AND ROSA RS. 2019. First record of dorsal and anal fin deformities in blue tang Acanthurus coeruleus (Acanthuridae, Actinopterygii) from northeastern Brazil. An Acad Bras Cienc 91: e2019637. DOI 10.1590/0001-3765201920190637.
\end{abstract}

\begin{abstract}
Dorsal and anal fin deformities in the blue tang Acanthurus coeruleus are reported for the first time from northeastern Brazil, based on observations during research dives at an artificial reef. Possible causative factors are discussed.
\end{abstract}

Key words: Acanthuridae, bony fish, fins, morphological deformities.

The first records of deformities in bony fish were documented on the 16th century (Gudger 1929, 1934, Berra and Au 1981). Since then, many teratology occurrences have been reported in different fish taxa (Lodi 1978, Lemly 2002, Boglione et al. 2006, Al-Mamry et al. 2010, Nagamuthu et al. 2014).

Among the morpho-anatomical deformities observed in fish, fins anomalies are the most severe, because fin development is an important feature from early life history and it is closely correlated with changes in swimming mode, swimming velocity and feeding strategies and preferences (Kendall et al. 1984, Blaxter 1988, Fukuhara 1992).

These anomalies are characterized by the total or partial lack of fins, and have been noted

Correspondence to: Camila Cristina Pires de Brito

E-mail: camila.cpbrito@gmail.com

ORCid: https://orcid.org/0000-0002-0871-6308 in both captive and wild marine fishes (e.g., Nematalosa nasus - Hussain 1979, Dentex dentex - Koumoundouros et al. 2001, Sparisoma cretense - Koumoundouros 2008, Diplodus sargus Boglione et al. 2013, Lates calcarifer - Cobcroft and Battaglene 2013). Despite implications about ecosystem quality (Lemly 2002, Jawad 2004), a better understanding is still needed on how deformities affect the survival of fish in the wild.

In order to contribute to the growing literature about deformities of fishes, this study reports one blue tang Acanthurus coeruleus (Bloch and Schneider 1801) displaying an unusual lunate concavity in the dorsal and anal fins, as well as a pronounced caudal peduncle morphology (Figure 1, Supplementary Information - Video S1) from Paraíba state, northeastern Brazil. The observations were made on December 9, 2016, April 29 and May 1,2017 , during research dives at the artificial reef 
a

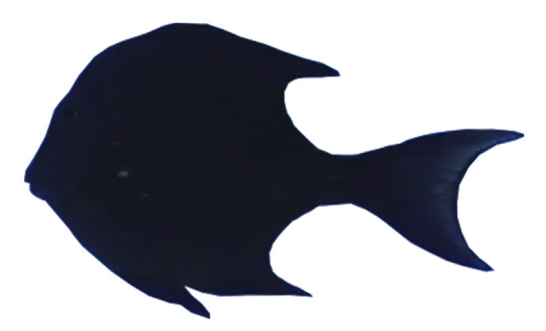

b

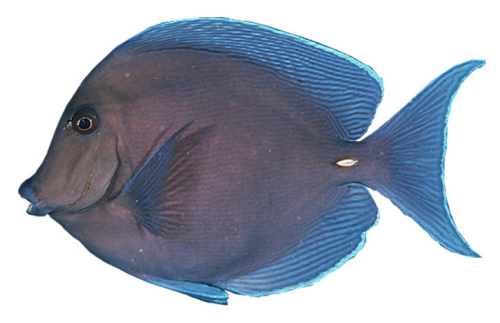

Figure 1 - Photographic comparison of: (a) Acanthurus coeruleus with dorsal and anal fin deformity observed in a coastal reef on northeastern Brazil; (b) normal profile of blue tang (adapted from Randall 1997).

“Queimado" $\left(07^{\circ} 05.07^{\prime}\right.$ S; 03444.852’ W), located in the Environmental Protected Area Queimado Shipwreck; at $18 \mathrm{~m}$ deep, in good conditions of visibility (approx. 35m).

This is the first report of type of such anomalies in A. coeruleus. Meanwhile, other deformities observed in Acanthuridae, were a juvenile Tomini surgeonfish Ctenochaetus tominiensis from the Philippines and Acanthurus nigrofuscus from Australia displaying an unusual double-tailed morphology (Goatley et al. 2018).

Despite the observed deformities observed in the blue tang, its body condition and swimming mode were normal. Acanthurid species primarily use the pectoral fins for propulsion (Morgan and Kramer 2004, Fulton et al. 2005). Consequently, the negative effect of the deformities in their locomotory potential in predation or escape activities is low. Furthermore, usually this species swim in mixed groups to exploit territories with high resource quality (i.e. higher biomass and algal diversity) (Wolf 1987, Ferreira et al. 1998), decreasing the predation risk (Alevizon 1976, Dias et al. 2001, Nunes et al. 2013).

Fish injuries by a putative predator (Honma 1994) were not considered as a possible cause of the deformity, since there were no signs of bites to the lunate concavity of the dorsal and anal fins.
Generally, these abnormalities take place during the early ontological stages, and their development may be due to pollutants, poor nutrition (Bengtsson 1988, Sfakianakis et al. 2006, Mazurais et al. 2009), inbreeding and mutations (Gjerde et al. 2005). The lack of additional data hampers the determination of the major drivers of this deformity.

\section{ACKNOWLEDGMENTS}

The authors acknowledge Mar Aberto Dive Center for the logistical support, specially to Diego Luna for taking the picture. We thank R. B. FranciniFilho for comments.

\section{AUTHOR CONTRIBUTIONS}

C.C.P.B., J.L.A., V.M.V., M.B.S. and R.S.R. conceived and designed the idea. C.C.P.B., J.L.A., V.M.V., M.B.S wrote the paper and led the revisions and C.C.P.B., J.L.A., V.M.V., M.B.S. and R.S.R critically reviewed and corrected the versions of the document.

\section{REFERENCES}

ALEVIZON WS. 1976. Mixed schooling and its possible significance in a tropical western Atlantic parrotfish and surgeonfish. Copeia 4: 796-798.

AL-MAMRY JM, JAWAD LA, AL-RASADY IH AND AL-HABSI SH. 2010. First record of dorsal and anal 
fin deformities in silver pomfrets, Pampus argenteus (Stromateidae, Actinopterygii). An Bio 32: 73-77.

BENGTSSON BE. 1988. Effects of pulp mill effluents on skeletal parameters in fish-a progress report. Water Sci Technol 20: 87-94.

BERRA TM AND AU R-J. 1981. Incidence of teratological fishes from Cedar Fork Creek, Ohio. Ohio J Sci 81: 225229.

BLAXTER JHS. 1988. Pattern and variety in development. In: Hoar WS and Randall DJ (Eds), Fish physiology XI. The physiology of developing fish. Part a. eggs and larvae, New York: AP, New York, USA, p. 1-58.

BOGLIONE C, COSTA C, GIGANTI M, CECCHETTI M, DI DATO P, SCARDI M AND CATAUDELLA S. 2006. Biological monitoring of wild thicklip grey mullet (Chelonlabrosus), golden grey mullet (Liza aurata), thin lip mullet (Liza ramada) and fathead mullet (Mugil cephalus) (Pisces: Mugilidae) from different Adriatic sites: meristic counts and skeletal anomalies. Ecol Indic 6: 712732.

BOGLIONE C, GISBERT E, GAVAIA P, WITTEN PE, MOREN M, FONTAGNÉ S AND KOUMOUNDOUROS G. 2013. Skeletal anomalies in reared European fish larvae and juveniles. Part 2: main typologies, occurrences and causative factors. Rev Aquacult 5: 121-167.

COBCROFT JM AND BATTAGLENE SC. 2013. Skeletal malformations in Australian marine finfish hatcheries. Aquacult 51-58.

DIAS TLP, ROSA ILAND FEITOZA BM. 2001. Food resource and habitat sharing by the three western South Atlantic surgeonfishes (Teleostei: Acanthuridae: Acanthurus) off Paraiba Coast, North-eastern Brazil. Aqua 5: 1-10.

FERREIRA CEL, GONÇALVES JEA, COUTINHO R AND PERET AC. 1998. Herbivory by the Dusky damselfish Stegastes fuscus (Cuvier, 1830) in a tropical rocky shore: effects on the benthic community. J Exp Mar Biol Ecol 229: 241-264.

FUKUHARA O. 1992. Study on the development of functional morphology and behavior of the larvae of eight commercially valuable teleost fishes. Contr Fish Res Jap Sea Block 25: 1-122.

FULTON CJ, BELLWOOD DR AND WAINWRIGHT PC. 2005. Wave energy and swimming performance shape coral reef fish assemblages. Proc R Soc B 272: 827-832.

GJERDE B, PANTE MA JR AND BAEVERFJORD G. 2005. Genetic variation for a vertebral deformity in Atlantic salmon (Salmo salar). Aquacult 244: 77-87.

GOATLEY CHR, WROE S, TEBBETT SB AND BELLWOOD DR. 2018. An evaluation of a double-tailed deformity in a coral-reef surgeonfish Acanthurus nigrofuscus (Acanthuridae) using micro-computed tomography. J Fish Biol 92: 1645-1650.
GUDGER EW. 1929. An adult pug-headed brown trout, Salmo fario, with notes on other pug-headed salmonids. Bull Am Mus Nat Hist 58: 531-559.

GUDGER EW. 1934. The Five Great Naturalists of the Sixteenth Century: Belon, Rondelet, Salviani, Gesner and Aldrovandi: A Chapter in the History of Ichthyology. Isis 22: $21-40$.

HONMA Y. 1994. Droplets from the Sado Marine Biological Station, Niigata University-VII. Further notes on some anomalous fishes. Rep Sado Mar Biol Stat Niigata Univ 24: 11-21.

HUSSAIN SM. 1979. Record of a clupeoid fish Nematalosa nasus without an anal fin. Hydrobiologia 63: 185-18.

JAWAD L. 2004. First record of an anomalous mullet fish (Mugil cephalus) from New Zealand. Tuhinga 15: 121124.

KENDALL-JR AW, AHLSTROM EH AND MOSER HG. 1984. Early life history stages of fishes and their characters, Ontogeny and Systematics of Fishes. Copeia 11-22.

KOUMOUNDOUROS G. 2008. First record of saddleback syndrome in wild parrotfish Sparisoma cretense (L., 1758) (Perciformes, Scaridae). J Fish Biol 72: 737-741.

KOUMOUNDOUROS G, DIVANACH P AND KENTOURI M. 2001. The effect of rearing conditions on development of saddleback syndrome and caudal fin deformities in Dentex dentex (L.). Aquacult 200: 285-304.

LEMLY AD. 2002. Symptoms and implications of selenium toxicity in fish: the Belews Lake case example. Aquat Toxicol 57: 39-49.

LODI E. 1978. Palla: A hereditary vertebral deformity in the Guppy, Poecilia reticulata Peters (Pisces, Osteichthyes). Genetica 48: 197-200.

MAZURAIS D, GLYNATSI N, DARIAS MJ, CHRISTODOULOPOULOU S, CAHU CL, ZAMBONINO-INFANTE J-L AND KOUMOUNDOUROS G. 2009. Optimal levels of dietary vitamin A for reduced deformity incidence during development of European sea bass larvae (Dicentrarchus labrax) depend on malformation type. Aquacult 294: 262270.

MORGAN IE AND KRAMER DL. 2004. The social organization of adult blue tangs, Acanthurus coeruleus, on a fringing reef, Barbados, West Indies. Environ Biol Fishes 71: 261-273.

NAGAMUTHU J, SAMBANDAMOORTHY P AND MUTHUKUMARASWAMY S.

2014. First record of abnormal fishes Epinephelus coioides and Cynoglossus cynoglossus

from the south-east coast of India. Mar Biodivers Rec 8: 1-5.

NUNES JACC, SAMPAIO CLS AND BARROS F. 2013. How wave exposure, group size and habitat complexity influence foraging and population densities in fishes of 
the genus Halichoeres (Perciformes: Labridae) on tropical rocky shores. Mar Biol 160: 2383-2394.

RANDALL JE. 1997. Randall's underwater photos. Collection of almost 2,000 underwater photos (slides). Unpublished. From FishBase, online database, viewed 17 October 2019, http://www.fishbase.org.

SFAKIANAKIS DG, GEORGAKOPOULOU E, PAPADAKIS I, DIVANACH P, KENTOURI M AND KOUMOUNDOUROS G. 2006. Environmental determinants of haemal lordosis in European sea bass,
Dicentrarchus labrax (Linnaeus, 1758). Aquacult 254: 5464.

WOLF NG. 1987. Schooling tendency and foraging benefit in the ocean surgeonfish. Behav Ecol Sociobiol 21: 59-63.

\section{SUPPLEMENTARY INFORMATION}

Video S1 - A blue tang Acanthurus coeruleus with an unusual dorsal and anal fin deformity, swimming in a coastal reef on northeastern Brazil. 